\title{
Hybrids and mixed pairs of Syrian and Great-spotted Woodpeckers in urban populations
}

\author{
Tomasz Figarski $^{1} \cdot$ Lukasz Kajtoch $^{1}$ (D)
}

Received: 5 May 2017 / Revised: 13 September 2017 / Accepted: 26 October 2017 / Published online: 6 November 2017

(C) The Author(s) 2017. This article is an open access publication

\begin{abstract}
The population structures of sympatric Syrian and Great-spotted Woodpeckers (SW and GW, respectively) in urban areas of Poland were investigated with respect to the occurrence of mixed pairs and hybrids. It was estimated that $5.3 \%$ of pairs were mixed and that these interspecific pairs mainly comprised SW or hybrid females and GW males. In total, $3.6 \%$ of observed individuals and $6.9 \%$ of dead birds were identified as hybrids. The sex ratio of hybrids was equal. These data suggest that hybridization between these woodpeckers could be an underestimated phenomenon with important consequences for ecological studies and conservation of the rare SW.
\end{abstract}

Keywords Dendrocopos syriacus · Dendrocopos major . Hybridization $\cdot$ Sex ratio

\section{Zusammenfassung}

Hybriden und gemischte Paare von Blut- und Buntspechten in städtischen Populationen

Die Populationsstrukturen sympatrisch vorkommender Blut- und Buntspechte (SW bzw. GW) in Stadtgebieten in

Communicated by F. Bairlein.

Electronic supplementary material The online version of this article (https://doi.org/10.1007/s10336-017-1513-0) contains supplementary material, which is available to authorized users.

Łukasz Kajtoch

lukasz.kajtoch@gmail.com

1 Institute of Systematics and Evolution of Animals Polish Academy of Sciences, Sławkowska 17, 31-016 Kraków, Poland
Polen wurden bezüglich des Vorkommens von gemischten Paaren und Hybriden untersucht. Es wurde geschätzt, dass 5.3\% der Paare gemischt waren und diese interspezifischen Paare hauptsächlich aus SW- bzw. Hybridweibchen und GW-Männchen bestanden. Insgesamt wurden 3.6\% der beobachteten Individuen und $6.9 \%$ der toten Vögel als Hybriden identifiziert. Das Geschlechterverhältnis der Hybriden war ausgeglichen. Diese Daten deuten darauf hin, dass Hybridisierung zwischen diesen beiden Spechtarten ein unterschätztes Phänomen sein könnte, das wichtige Konsequenzen für ökologische Studien und den Schutz des seltenen Blutspechts hat.

\section{Introduction}

Hybridization is a phenomenon that shapes the diversity of organisms, but is often underestimated in biological studies (Baack and Rieseberg 2007). Interspecific cross-breeding is relatively common in birds (Randler 2006), or perhaps this group is just better investigated because detection of hybrid individuals is easier, due to characteristic plumage and voices. Indeed, there are numerous studies that describe hybrids in various groups of birds. This propensity to hybridize probably contributes to the high rate of bird speciation and the presence of multiple species groups or species pairs of relatively young evolutionary age (Prager and Wilson 1975) as hybrids in birds are more frequent in sister than non-sister taxa (Gholamhosseini et al. 2013).

Hybrids have been reported quite often between pairs of woodpecker species and the majority of cases concern species from North and South America (e.g., Seneviratne et al. 2016). In Europe, hybrid individuals have been reported between the Green Picoides viridis and Grey-headed $P$. canus Woodpeckers (Lawicki et al. 2015) and between the Great-spotted Dendrocopos major (hereafter GW) and Syrian D. syriacus (hereafter SW) Woodpeckers (Gorman 1997; 
Dudzik and Polakowski 2011). The species in the latter pair are sibling taxa, as they have very similar phenotypes and genotypes, whereas they differ with respect to their ecologies (habitat choice) and ethology (territorial behaviour), but SW is much less known than GW (Pasinelli 2006). Moreover, SW has expanded into the range of GW in Europe (Michalczuk 2014), which has enabled and facilitated their crossbreeding. It is possible to identify $\mathrm{GW} \times \mathrm{SW}$ hybrids on the basis of their plumages; however, their characters vary substantially (Dudzik and Polakowski 2011). Furthermore, preliminary genetic studies have confirmed hybrid genotypes and indicated that hybrids are fertile as there were apparent backcrosses (Michalczuk et al. 2014). On the other hand, there have been no studies showing the structure of the sympatric populations with respect to the presence of mixed pairs and hybrids.

The aim of this study was to estimate the following: (1) what is the share of mixed pairs in urban populations and whether the cross-breeding is random with respect to sexes; and (2) how frequent are hybrid birds and what is the sex ratio of hybrids.

\section{Materials and methods}

The present study was based on woodpecker inventories executed during a project on SW and GW ecology and ethology in urban populations. Data were collected in 20132015 years in four urban areas (cities/towns) in Poland: (1) Radom, centre point $51.4024^{\circ} \mathrm{N}, 21.1650^{\circ} \mathrm{E}$, (2) GrodziskMilanówek, c.p. $52.1145^{\circ} \mathrm{N}, 20.6614^{\circ} \mathrm{E}$, (3) Krakow, c.p. $50.0205^{\circ} \mathrm{N}, 19.9963^{\circ} \mathrm{E}$ and (4) Wieliczka, c.p. $49.9813^{\circ} \mathrm{N}$, $20.0685^{\circ} \mathrm{E}$; in total, $80 \mathrm{~km}^{2}$ ). Details about the study areas, inventory techniques and data collection are presented elsewhere (Figarski 2014; Kajtoch and Figarski 2017). The total number of pairs of both species, mixed pairs (of [apparently] "pure" individuals or with hybrids, based on plumage characters) and hybrid individuals were counted and used to describe the population structure of these species in urban ecosystems. Next, we summarized all data about mixed pairs collected during inventories, obtained from observers in these cities and its vicinities, and data available in the work of Dudzik and Polakowski (2011). This database was used to estimate the frequency of sexes of particular species in mixed pairs. Finally, we used data about dead birds delivered since 2013 to the Collection Unit of the Institute of Systematics and Evolution of Animals, Polish Academy of Sciences in Krakow (hereafter ISEA PAS). We considered only birds found dead in Krakow city, and we restricted the analysis to juveniles, which prevailed among dead woodpeckers. We considered hybrids to be individuals that possessed intermediate characters in their plumage (see details specified in Table 1 and some exemplary photographs of hybrids shown in supplementary file 1).

\section{Results}

In total, we identified 94 territories of woodpeckers and 192 individuals, including hybrids (regardless if paired or not). We found that for each "pure" pair of the GW, there was 0.7 pair of SW, but this ratio differed greatly between study areas (Table 2). Only in seven cases did conspecific territories $\left(\mathrm{SW}_{\widehat{\lambda}} \times \mathrm{SW}+\right.$ with $\mathrm{GW} \hat{\bigcirc} \times \mathrm{GW}+$ ) overlap to some extent (7.4\% of territories, Table 2 ). On average only $2.1 \%$ of territories (two pairs, Table 2) were formed by birds belonging to different species, but if also considering pairs comprising at least one hybrid, it was on average 5.3\% (five pairs, Table 2). In total only seven individuals ( $3.6 \%$, Table 2 ) could be identified as hybrids on the basis of their mixed plumage characters. Among these hybrids there were four females and three males [sex ratio $(f / m)=1.3$ ], but if also considering hybrids
Table 1 Basic characteristics that allow for differentiation of Syrian and Great-spotted Woodpeckers

\begin{tabular}{lll}
\hline Characteristic & Dendrocopos syriacus & Dendrocopos major \\
\hline Outer rectrices & Black with white bars & White with black bars \\
Undertail coverts & Pink & Red (but sometimes pinkish in juvs) \\
Flank feathers & Clearly streaked & Generally without stripes \\
Breast feathers & Fuzzy pink belt in juvs & Clean (whitish) \\
Cheek & Fuzzy dark spot beyond the eye in juvs & Clean (whitish) \\
Post-auricular stripe & Lack of black line (“white neck") & Black, connected with hind-crown, \\
& & except some juvs \\
Red nape (in males) & Short & Large \\
Lore feathers & Whitish & Black \\
Voice & Quieter, milder & Louder, stronger \\
\hline
\end{tabular}

Hybrid individuals usually have a mixture of these characters. See https://static-content.springer.com/esm/ art\%3A10.1007\%2Fs10336-014-1040-1/MediaObjects/10336_2014_1040_MOESM2_ESM.tif where some of these characters are marked on photographs of "pure" Syrian Woodpecker, "pure" Great-spotted Woodpecker and hybrid of both species 
Table 2 Basic characteristics of Syrian and Great-spotted Woodpecker populations in urban landscapes of Poland with emphasis on mixed pairs and hybrids occurrence

\begin{tabular}{|c|c|c|c|c|c|c|c|c|c|c|}
\hline \multirow[t]{2}{*}{ Characteristic } & \multicolumn{2}{|l|}{ Krakow } & \multicolumn{2}{|c|}{ Wieliczka } & \multicolumn{2}{|l|}{ Radom } & \multicolumn{2}{|c|}{$\begin{array}{l}\text { Grodzisk- } \\
\text { Milanówek }\end{array}$} & \multicolumn{2}{|l|}{ Total } \\
\hline & Number & $\%$ & Number & $\%$ & Number & $\%$ & Number & $\%$ & Number & $\%$ \\
\hline Great-spotted Woodpecker territories & 4 & 22.2 & 10 & 66.7 & 3 & 16.7 & 35 & 81.4 & 52 & 55.3 \\
\hline Syrian Woodpecker territories & 12 & 66.7 & 4 & 26.6 & 14 & 77.8 & 7 & 16.3 & 37 & 39.4 \\
\hline Overlapping territories & 0 & 0.0 & 3 & 20.0 & 1 & 5.5 & 3 & 7.0 & 7 & 7.4 \\
\hline Mixed pairs ("pure" birds) & 2 & 11.1 & 0 & 0.0 & 0 & 0.0 & 0 & 0.0 & 2 & 2.1 \\
\hline Mixed pairs (with hybrids) & 0 & 0.0 & 1 & 6.7 & 1 & 5.5 & 1 & 2.3 & 3 & 3.2 \\
\hline $\begin{array}{l}\text { Total no. of hybrid individuals (solitary } \\
\text { and paired) }\end{array}$ & 1 & 2.7 & 1 & 3.3 & 3 & 7.9 & 2 & 2.3 & 7 & 3.6 \\
\hline
\end{tabular}

listed in the work of Dudzik and Polakowski (2011) (four females and five males), the sex ratio $(\mathrm{f} / \mathrm{m})$ was 1.0.

Considering all available observations of mixed pairs (this study and some occasional observations, including data from Dudzik and Polakowski (2011)) $(N=14$, including four pairs with hybrid members) with data available on the sex and species of individuals, $71.4 \%$ of pairs comprised a SW female and a GW (nine cases) or hybrid male (one case). Described in another way, $92.8 \%$ of pairs comprised a SW or hybrid female, and a GW (ten cases), SW (two cases) or hybrid male (one case).

Among dead juveniles collected from the city of Krakow, there were a total of 29 birds, 22 of which were assigned to $\mathrm{GW}$, five to SW and two had intermediate characters $(6.9 \%$ of birds were probable hybrids).

\section{Discussion}

Woodpeckers are a group of birds with relatively common interspecific cross-breeding (Gorman 1997; Ławicki et al. 2015). It seems that this phenomenon is especially pronounced at the border of two species' ranges or when one species changes its range and starts to breed sympatrically with its congener. In such cases, the number of individuals of one or both species is low, and a lack of mates of the same species forces birds to mate and breed interspecifically. The latter case (range change) is especially interesting in the case of the SW and GW pair, as the former species is a newcomer in Central and Eastern Europe (Michalczuk 2014). Hybrids of both species have been reported across the SW range established in Central Europe since its expansion from the Middle East across the Balkans in the twentieth century (Michalczuk 2014). Notably, the number of hybrids seems to increase towards to the north, and in Poland such mixed birds are present more than just incidentally (Dudzik and Polakowski 2011). The presented note shows for the first time that mixed pairs of these woodpecker species (or hybrids) can constitute approximately 5.3\% of woodpecker populations, at least in urban areas. The share of hybrid birds in these populations is more difficult to establish as probably only first generation hybrids can be easily identified in the field. Preliminary genetic studies have suggested that even approximately $20 \%$ of woodpeckers from sympatric populations could be of hybrid origin (Michalczuk et al. 2014). Examination of dead juveniles supports this suggestion as $7 \%$ of birds display intermediate plumage. It is also interesting that among hybrids there was an equal share of females and males. The question is if all hybrids originated from mixed pairs or if some hybrids resulted from extra-pair copulation, which is a phenomenon not observed in GW (Michalek and Winkler 2001) (there are no such studies for SW).

Finally, this study presents for the first time data that leads to the hypothesis that cross-breeding between SW and GW is not random, as almost all mixed pairs were found to comprise SW or hybrid females and GW males. This suggests the existence of some factors responsible for this sexbiased mating. Some differences in ethology of these species may make SW females more likely to mate with GW if there is a lack of unpaired SW males (Figarski 2017). It is also interesting that there were several examples of mixed pairs in which one bird was of hybrid phenotype, which suggests that D.syriacus $\times$ D.major offsprings should be viable (which is consistent with preliminary genetic data; Michalczuk et al. 2014). Also, the even sex ratio in hybrid individuals indicates that there should not be negative effects of interspecific cross-breeding.

This study brings new light on hybridization of SW and GW. Detailed population genetic analysis on numerous specimens would confirm or extend the knowledge on the extent of this phenomenon. These data could be important not only from an evolutionary perspective but also for the conservation of SW, which is protected in the European Union (annexed in the Birds Directive) and is still rare in some countries like Poland, Czechia and Austria. Hybridization 
could be one of the crucial factors, apart from habitat loss, responsible for halting expansion and further decline of the species in the northernmost part of its range.

Acknowledgements We are grateful for people who collected and stored dead woodpeckers in the Collection Unit of ISEA PAS in Krakow, with special thanks to "Dzika Klinika" (Joanna D. Wójcik) and "Vetika" (Karolina Ptak). Some photographs of woodpecker hybrids presented in supplementary file were kindly provided by Jacek Niemiec, Paweł Malczyk and Marek Elas. The paper has greatly benefited from the constructive comments of an anonymous reviewer. This study was supported by the grant for young scientists 6085/E-47/M/2013-2015 funded by the ISEA PAS from resources provided by the Polish Ministry of Higher Education and Science (to T. Figarski).

\section{Compliance with ethical standards}

This study complies with current Polish and international laws.

Conflict of interest The authors declare no conflict of interest.

Open Access This article is distributed under the terms of the Creative Commons Attribution 4.0 International License (http://creativecommons.org/licenses/by/4.0/), which permits unrestricted use, distribution, and reproduction in any medium, provided you give appropriate credit to the original author(s) and the source, provide a link to the Creative Commons license, and indicate if changes were made.

\section{References}

Baack EJ, Rieseberg LH (2007) A genomic view of introgression and hybrid speciation. Curr Opin Genet Dev 17:513-518

Dudzik K, Polakowski M (2011) Przypadki łęgów mieszanych oraz problematyka identyfikacji mieszańców międzygatunkowych dzięcioła białoszyjego Dendrocopos syriacus i dzięcioła dużego Dendrocopos major w Polsce. Chrońmy Przyr Ojcz 67:254-260 (in Polish with English summary)

Figarski T (2014) Habitat characteristics of the Syrian Woodpecker Dendrocopos syriacus in the city of Radom, Poland-preliminary results. In: Indykiewicz P, Böhner J (eds) Urban Fauna. Animal, man, and the city-interactions and relationships. University of Science and Technology, Bydgoszcz, pp 225-234
Figarski T (2017) Contrasting seasonal reactions of two sibling woodpeckers to playback stimulation in urban areas - implications for inventory and monitoring of the Syrian woodpecker. Behaviour 154:981-996. https://doi.org/10.1163/1568539X-00003452

Gholamhosseini A, Vardakis M, Aliabadian M, Nijman V, Vonk R (2013) Hybridization between sister taxa versus non-sister taxa: a case study in birds. Bird Study 60:195-201

Gorman G (1997) Hybridisation by Syrian Woodpeckers. Brit Birds 90:578

Kajtoch $€$, Figarski T (2017) Comparative distribution of Syrian and Great spotted woodpeckers in different landscapes of Poland. Folia Zool 66:29-36

Ławicki Ł, Cofta T, Beuch S, Dmoch A, Sikora A, Aftyka S, Czechowski P, Bocheński M, Sieczak K, Mazgaj S (2015) Identification and occurrence of Grey-headed $\times$ European Green Woodpecker hybrids in Poland. Dutch Birding 37:215-228

Michalczuk J (2014) Expansion of the Syrian Woodpecker Dendrocopos syriacus in Europe and Western Asia. Ornis Pol. 55:149-161 (In Polish with English summary)

Michalczuk J, McDevitt AD, Mazgajski TD, Figarski T, Ilieva M, Bujoczek M, Malczyk P, Kajtoch $Ł$ (2014) Tests of multiple molecular markers for the identification of Great Spotted and Syrian Woodpeckers and their hybrids. J Ornithol 155:591-600

Michalek KG, Winkler H (2001) Parental care and parentage in monogamous great spotted woodpeckers (Picoides major) and middle spotted woodpeckers (Picoides medius). Behaviour 138:1259-1285

Pasinelli G (2006) Population biology of European woodpecker species: a review. Ann Zool Fennici 43:96-111

Prager ER, Wilson AC (1975) Slow evolutionary loss of the potential for interspecific hybridization in birds: a manifestation of slow regulatory evolution. Proc Nat Acad Sci USA 72:200-204

Randler C (2006) Extrapair paternity and hybridization in birds. J Avian Biol 37:1-5

Seneviratne SS, Davidson P, Martin K, Irwin DE (2016) Low levels of hybridization across two contact zones among three species of woodpeckers (Sphyrapicus sapsuckers). J Avian Biol 47:887-898 